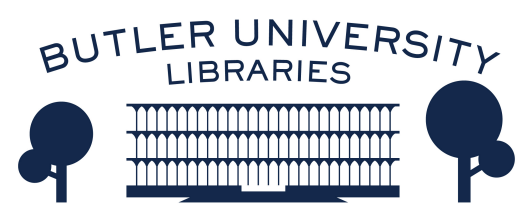

Journal of Hindu-Christian Studies

Volume 19

Article 4

January 2006

\title{
Introductory Information and Introduction
}

Bradley Malkovsky

Follow this and additional works at: https://digitalcommons.butler.edu/jhcs

Part of the Religion Commons

\section{Recommended Citation}

Malkovsky, Bradley (2006) "Introductory Information and Introduction," Journal of Hindu-Christian Studies: Vol. 19, Article 4.

Available at: https://doi.org/10.7825/2164-6279.1359

The Journal of Hindu-Christian Studies is a publication of the Society for Hindu-Christian Studies. The digital version is made available by Digital Commons @ Butler University. For questions about the Journal or the Society, please contact cbauman@butler.edu. For more information about Digital Commons @ Butler University, please contact digitalscholarship@butler.edu. 


\section{EDITORS}

EDITOR:

Bradley J. Malkovsky

232 Malloy Hall

University of Notre Dame

Notre Dame, IN 46556 USA

email: hcsb.1@nd.edu
CO-EDITOR:

Anand Amaladass

Institute of Philosophy and Culture

81 Lattice Bridge Road

Thiruvanmiyur, Madras

INDIA 600041

EDITOR'S ASSISTANT: Sarah Morice Brubaker

\section{EDITORIAL ADVISORY BOARD}

R. Balasubramanian

University of Pondicherry

Klaus Klostermaier

University of Manitoba

Francis X. Clooney, S.J.

Harvard University

Julius Lipner

University of Cambridge

John Carman

Harvard Divinity School

U. R. Anatha Murthy

Mahatma Gandhi University

Margaret Chatterjee

Indian Institute of Advanced Study, Simla
Raimundo Panikkar

Univeristy of California, Santa Barbara (Emeritus)

S. Cromwell Crawford

University of Hawaii at Manoa

David C. Scott

United Theological College

J. T. K. Daniel

Serampore College

R. Vijayalakshmi

International Institute for Tamil Studies

Diana Eck

Harvard University

\section{EDITORIAL POLICY}

The Journal of Hindu-Christian Studies is an annual scholarly journal published jointly at the University of Notre Dame and at the Institute of Philosophy and Culture, Madras, India. It is the official publication of the Society for Hindu-Christian Studies.

The aim of the Journal is to create a worldwide forum for the presentation of Hindu-Christian scholarly studies, book reviews, and news of past and upcoming events. Materials selected for publication will be balanced between historical research and contemporary practice and, where possible, will employ analytical and theoretical analysis set within the context of our shared contemporary experience. Contributions are invited and may be addressed to either the Editor or the Co-Editor. Articles of roughly 4000 words are preferred, though occasionally longer pieces will be published. Send manuscript in paper form as well as on diskette. A style sheet is available on request. The Journal adopts a policy of non-gender-specific language where applicable. All articles are subject to review before acceptance and may be edited in the course of publication.

\section{SUBSCRIPTION INFORMATION}

An annual subscription is included with membership in the Society for Hindu-Christian Studies. Membership annual dues: US dollars \$35; Students, US dollars \$15; Special 3-year rate, US dollars \$80. Subscription only rates (individuals and institutions): US dollars $\$ 15$; Overseas address, US dollars $\$ 16$. Single copies of back issues: US dollars $\$ 15$. No other currencies can be accepted. Make check or money order in US dollars payable to the Society for Hindu-Christian. Studies and mail to Bradley Malkovsky at the address above. For subscription information within India, please write to Anand Amaladass at the address above. The Journal is indexed in the ATLA Religion Database, published by the American Theological Library Association. 


\section{EDITOR'S INTRODUCTION}

THE topic of book banning and religious censorship has attracted much scholarly attention of late in the Hindu-Christian and Indian-Western encounter. The Journal of Hindu-Christian Studies carries forth that discussion in its first four articles this year.

Adheesh Sathaye recounts the events surrounding the 2004 "Bhandarkar incident" in Pune when the Bhandarkar Oriental Research Institute (BORI) was ransacked by followers of the Sambhaji Brigade in response to the publication of James W. Laine's biographical study, Shivaji: Hindu King in Islamic India (2003). Laine's book was subsequently censored throughout India. Was the attack on BORI simply a Hindu backlash against the offensive misrepresentation of a Hindu hero and his mother by a Western "outsider," or ought other factors also be considered? Sathaye suggests that inner-Hindu "caste politics" also played a role here, i.e. that the attack was in part the expression of low-caste animosity towards a scholarly institution identified with Brahmanic hegemony. The controversy over Laine's book ought to be understood within the context of a Hindu power struggle to "redefine and control the knowledge of Shivaji."

Gerald Larson likewise takes up the question of censorship in India, but he places it in a broader, context than simply the problematics of Western scholarship of Hinduism. He notes that since India's independence the major book banning controversies have involved Hindu-Muslim interactions. By contrast, secular Western scholarship on Hinduism has become overtly controversial only since the 1990s. Larson goes on to describe four types of studies of religion linked to various Hindu communities both in India and abroad, all four of which he characterizes as "Neo-Hindu." Each has its own perspective on the retrieval of India's past and the way it interprets the meaning and value of Hinduism and Indian civilization today.

For Jeffrey Kripal contemporary book banning controversies in India are illustrative of the problems faced by creative and innovative scholars of religion in their struggle against the "conservative concerns and prohibitions of religious orthodoxy." This struggle is especially animated in discussions linking sexuality with religion. This is as true of Christianity as it is of Hinduism and other religions. The modern critical study of religion struggles for its freedom against the dictates of rigid religious authority and power. Yet a closer historical examination of these same religions also reveals at times bold and provocative innovations from within that serve to deepen awareness that "the spiritual and the sexual are organically, energetically, metaphysically related." Here Kripal cites Tantra as an example.

In the final of the four essays Daniel Sheridan provides an historical overview of the banning or prohibiting of books in the Catholic Church, starting with the formation of the biblical canon and the condemnation of the works of Origen and other theologians in the earliest Christian centuries, continuing with the banning of the works of John Wyclif and John Hus in the $15^{\text {th }}$ century and the condemnation of Protestant founders like Martin Luther and John Calvin in the $16^{\text {th }}$. It was during the Catholic Counter-Reformation that the Index of Prohibited Books was established in 1557. Catholics were prohibited from reading material that was considered contrary to the faith and morals of the Church. The number of books on that list grew to over 4000 before the Index was terminated in 1966, in the aftermath of the Second Vatican Council (1962-65) and its affirmation of freedom of inquiry, freedom of religious choice, and its new emphasis on human dignity. For Sheridan both Hindu and Christian scholars should be able to pursue the truth about God, nature, and the human person without the impediment of book prohibitions and the prevention of free scholarship.

Bradley Malkovsky University of Notre Dame 